\title{
ZASADA SZYBKOŚCI \\ POSTĘPOWANIA ADMINISTRACYJNEGO W WYBRANYCH KRAJACH SKANDYNAWSKICH I POLSCE*
}

\section{WPROWADZENIE}

Struktura każdego postępowania o charakterze prawnym nieodmiennie łączy się z ideą sprawiedliwości proceduralnej. Przestrzeganie przez organy prowadzące postępowanie standardów proceduralnych wpływa na budowanie zaufania obywateli do organów władzy, a w tym zakresie kluczowa rolę spełnia terminowe załatwianie spraw $^{1}$. Jednym z największych paradoksów każdego rodzaju postępowania o charakterze prawnym jest konieczność zrównoważenia oczekiwania stron co do możliwie najszybszego załatwienia sprawy z niezbędnością zachowania obowiązku przestrzegania norm gwarantujących uznanie danego procesu i rozstrzygnięcia $\mathrm{w}$ nim zapadającego za sprawiedliwe. Najogólniej rzecz ujmując, można przyjąć, że najkorzystniejsze jest rozwiązanie, w którym możliwe jest wydanie najbardziej prawidłowego orzeczenia w możliwie najszybszym postępowaniu ${ }^{2}$.

Z punktu widzenia interesów jednostki, która domaga się ochrony swoich praw przed organami administracji publicznej lub sądami, niewątpliwie jednym z najistotniejszych zagadnień z punktu widzenia jednostki jest czas trwania postępowania ${ }^{3}$. Przewlekłość postępowania administracyjnego jest od dawna jednym z największych problemów w zakresie działania administracji publicznej, szczególnie w kontekście postępowania z udziałem przedsiębiorców, co jest szeroko dyskutowane w doktrynie prawa procesowego administracyjnego ${ }^{4}$. W doktrynie podkreśla się, że zasadniczym postulatem w zakresie kształtu postępowań administracyjnych i sądowych jest to, aby jak najpełniej realizowały one zasady szybkości postępowania i ekonomii procesowej ${ }^{5}$. Wyrażane jest nawet stanowisko wskazujace na to, że uzyskanie możliwie naj-

\footnotetext{
* Publikacja powstała w ramach stażu naukowego sfinansowanego w drodze konkursu ze środków statutowych Wydziału Prawa i Administracji Uniwersytetu im. Adama Mickiewicza w Poznaniu w latach 2017-2018.

${ }^{1}$ Kmieciak (1994): 57; (1994): 57.

${ }^{2}$ Weitz (2009).

${ }^{3}$ Kmieciak (2018): 35.

${ }^{4}$ Gurba (2018): 83 i powołana tam literatura; Wojciechowska (2018): 407.

${ }^{5}$ Sawczyn (2017): 103.
} 
większej efektywności postępowania powinno być istotą wszystkich wysiłków w zakresie zmian kształtu procedury administracyjnej ${ }^{6}$.

Sprawność i szybkość postępowania administracyjnego jest również obecna w międzynarodowej dyskusji dotyczącej kształtu postępowania administracyjnego, chociażby w regulacjach wspólnotowych - w art. 41 Karty praw podstawowych przewidziano, że każdy ma prawo do bezstronnego i rzetelnego załatwienia swojej sprawy w rozsądnym terminie przez instytucje, organy i agencje Uniī 7 W przypadku aktów prawa miękkiego przewidziano regulacje zmierzające do szybkiego załatwienia sprawy. Europejski kodeks dobrej praktyki administracyjnej (funkcjonujaccy w Polsce jako Europejski kodeks dobrej administracji) również przewiduje prawo obywatela do sprawnego postępowania administracyjnego, co oznaczać powinno nakaz jak najszybszego załatwienia sprawy przy zachowaniu poszanowania pozostałych zasad proceduralnych ${ }^{8}$. Problem szybkości postępowania administracyjnego jest więc poruszany nie tylko w polskiej nauce prawa procesowego ${ }^{9}$. Z perspektywy prawa europejskiego wypada zauważyć, że kształt procedury administracyjnej pozostawiony został uznaniu państwa członkowskiego. Za niezbędne uznaje się, by procedura ta ukształtowana była w sposób pozwalajacy na zachowanie równego traktowania i efektywności ${ }^{10}$. Tę ostatnią cechę łączyć można ze sprawnością postępowania rozumianą w ujęciu czasowym.

Przedmiotem niniejszego artykułu jest analiza regulacji dotyczacych sprawności postępowania administracyjnego, w tym w szczególności norm ustanawiających terminy załatwienia spraw administracyjnych i środków prawnych przysługujacych stronom w celu zagwarantowania realizacji przez organ administracji publicznej obowiązku załatwienia sprawy bez zbędnej zwłoki. Należy jednocześnie zastrzec, że w odniesieniu do prowadzonych poniżej rozważań przyjęte pojęcie postępowania administracyjnego, identyfikuje się z kategorią postępowania jurysdykcyjnego ${ }^{11}$. Tym samym zasadniczo poza zakresem rozważań pozostawiono inne aniżeli forma procesu administracyjnego formy działania organów administracji publicznej. Oczywiste jest, że organizacyjna sprawność szeroko pojętej administracji publicznej (choćby z uwzględnieniem uwarunkowań kadrowych czy finansowych) ma również wpływ na tok postępowania administracyjnego. Ramy niniejszego opracowania ograniczone zostaną jednak wyłącznie do aspektów procesowych. Założeniem, które zostanie zweryfikowane w toku prowadzonych rozważań, jest stanowisko, że obecnie obowiązujące regulacje w polskim systemie prawnym zapewniają możliwość realizacji prawa jednostki do rozpatrzenia sprawy w sposób sprawiedliwy, a równocześnie bez nieuzasadnionej zwłoki i nie odbiegają od rozwiązań przyjętych w innych krajach Unii Europejskiej. Z uwagi

${ }^{6}$ Kovač, Kotnik (2018): 531.

7 Dz. Urz. UE 2010/C 83/02.

8 Świątkiewicz (2013): 37.

${ }^{9}$ Szerzej Kmieciak (2014): 63-68.

${ }^{10}$ Bignami (2004): 6.

11 Ostojski (2017): 80; co do możliwości szerokiego rozumienia terminu „postępowanie administracyjne” zob. Niewiadomski (2002): 12; Adamiak (2015): 11. 
na ramy niniejszego artykułu do porównania modeli postępowania administracyjnego w omawianym zakresie wybrano dwie procedury skandynawskie - szwedzką i fińska. Powszechnie przyjmuje się, że państwa skandynawskie stanowią dojrzałe demokracje, które oceniane są pozytywnie ze względu na wysoki standard obsługi administracyjnej obywateli i gwarancje ochrony praw człowieka $^{12}$. Szwedzki model postępowania administracyjnego wybrany został dlatego, że od 1 lipca 2018 r. obowiązuje w nim nowy kodeks (akt) regulujacy przebieg postępowania administracyjnego. Z kolei fiński system administracji publicznej uważany jest za jeden najbardziej przyjaznych odbiorcy. Zarówno w Szwecji, jak i Finlandii wprowadza się szereg usprawnień w zakresie upowszechnienia e-administracji, również w odniesieniu do postępowania administracyjnego. W Szwecji wprowadzono program majacy poprawić efektywność zarządzania, który jest zbiorczo określany „Kungsbacka 2020”13. Finlandia zaś jest krajem, który promuje załatwienie spraw w postępowaniu administracyjnym środkami komunikacji elektronicznej ${ }^{14}$. W szczególności należy rozważyć, czy instytucje zakodowane w wybranych uregulowaniach obcych lepiej rozwiązują problem przewlekłości postępowania administracyjnego, a jeżeli tak - czy konstrukcje te nadawałyby się w jakimś zakresie do przetransponowania do rodzimego kodeksu postępowania administracyjnego. Rozważania zostały ograniczonego do dwóch wskazanych wyżej modeli postępowania administracyjnego przede wszystkim z uwagi na ich efektywność, a także ograniczone ramy opracowania.

\section{REGULACJE ZMIERZAJĄCE DO ZAPEWNIENIA SZYBKOŚCI POSTEPOWANIA ADMINISTRACYJNEGO OBOWIĄZUJĄCE W PRAWIE SZWEDZKIM}

W pierwszej kolejności trzeba wskazać, że - jak podnosi się w piśmiennictwie - szwedzki system prawny rozwijał się stabilnie, a zarazem w odosobnieniu od wpływów prawa anglosaskiego czy też kontynentalnego ${ }^{15}$. Jeśli chodzi o działanie administracji publicznej, to w doktrynie szwedzkiego prawa administracyjnego dobitnie podkreśla się, że administracja publiczna powinna działać w sposób niezależny, zgodnie z ustawą i na własną odpowiedzialnośćc ${ }^{16}$. Organy administracji publicznej zorganizowane są jako niezależne instytucje, cieszące się praktycznie taką samą ochroną konstytucyjną jak sądy podczas podejmowania indywidualnych decyzji ${ }^{17}$.

\footnotetext{
${ }^{12}$ Pecaric (2011): 399; Raport Freedom House (2016) - Freedom in the World 2016.

${ }^{13}$ Orzeczenie Sądu Administracyjnego w Goteborgu z 26 maja 2014 r., Digital Evidence and Electronic Signature Law Review 12, 2015: 103.

${ }^{14}$ eGovernment in Finland (<https://joinup.ec.europa.eu/sites/default/files/inline-files/eGovernmnent\%20in\%20Finland\%20-\%20February\%202016\%20-\%2018_00\%20-\%20v2_00.pdf>).

${ }^{15}$ Szewczyk (2010): 372; Ortwein (2003): 405-406.

${ }^{16}$ Malmberg (2014): 359.

${ }^{17}$ Wenander (2018): 4.
} 
Postępowanie administracyjne jest skodyfikowane od $1971 \mathrm{rr}^{18} \mathrm{~W}$ ostatnich latach jednak dostrzeżono pewne niedoskonałości kształtu procedury administracyjnej, w szczególności w odniesieniu do problemu realizacji gwarancji rozpoznania sprawy bez nieuzasadnionej zwłoki. W 2008 r. podjęto prace zmierzające do wprowadzenia nowych unormowań, w tym w szczególności nowelizacji regulacji związanych z czasem załatwienia sprawy oraz środków służących zwalczaniu opóźnienia w działaniu organów administracji publicznej ${ }^{19}$. Ich efektem było uchwalenie nowego aktu prawnego regulujacego przebieg postępowania administracyjnego. Nowa ustawa o postępowaniu administracyjnym - Förvaltningslag - obowiąuje od 1 lipca $2018 \mathrm{r} .{ }^{20}$ Wprowadziła ona dość istotne zmiany $\mathrm{w}$ stosunku do poprzednio obowiąujacych regulacji, w tym również w zakresie dotyczącym sprawności postępowania administracyjnego.

W pierwszej kolejności należy podkreślić, że w ustawie wprost wskazano ogólne i podstawowe zasady postępowania administracyjnego, takie jak praworządność, obiektywizm i proporcjonalność. Podobnie jak w przypadku ustawy fińskiej (o czym niżej), nowa regulacja odchodzi od koncepcji „sprawowania władzy publicznej", kładąc nacisk na usługowy charakter działań administracji publicznej, w tym również tych czynności, które są podejmowane w ramach postępowań administracyjnych o charakterze jurysdykcyjnym (§ 7-8 SCAP). Istotnym czynnikiem przy wykładni treści norm prawnych ma być pragmatyzm w działaniach organów administracji publicznej ${ }^{21}$. Organy administracji publicznej - zachowując niezależność od innych władz i bezstronność w rozstrzyganiu sprawy - powinny dążyć do zapewnienia możliwie największej dostępności w zakresie wykonywanych zadań publicznych, pomocy jednostce w załatwieniu jej sprawy oraz współpracy z innymi organami administracji publicznej ${ }^{22}$. Nowe regulacje zwiększają również przejrzystość i transparentność postępowań. Obowiązkiem organu administracji publicznej jest zapewnienie elastyczności i prostoty kontaktów strony z władzą publiczna (§ 6 SCAP), jak również zapewnienie dostępności do bezpośredniego kontaktu obywatela z przedstawicielami władzy publicznej (§ 7 SCAP).

W odniesieniu do terminów załatwienia spraw nowa ustawa utrzymuje ogólną regułę, że sprawy powinny być rozpatrywane zarówno sprawnie, szybko, ekonomicznie, jak i najbardziej efektywnie, bez uszczerbku dla pewności prawnej podmiotów administrowanych (§ 9 SCAP). Istotne modyfikacje w stosunku do poprzedniej kodeksowej regulacji dotyczą określenia terminu załatwienia sprawy i możliwości wymuszenia jego przestrzegania na organie prowadzącym postępowanie. We wcześniejszej regulacji kodeksowej brakowało określenia ustawowego terminu załatwienia sprawy. Okres, w jakim sprawa powinna być zakończona, wynikał z orzecznictwa sądowego i praktyki dzia-

18 Szerzej co do historii kodyfikacji szwedzkiego postępowania administracyjnego - Szewczyk (2010): 372-373.

19 Lofven (2017): 20.

${ }^{20}$ Förvaltningslag z 28 września 2017. r. (dalej jako: SCAP); <http://rkrattsbaser.gov.se/ sfst?bet=2017>: 900 .

21 Bogdan (2013): 76.

22 Nergelius (2011): 84. 
łań organów administracji publicznej ${ }^{23}$. Nowo wprowadzone regulacje dokonują w tym zakresie istotnej zmiany. Zmiany dotyczą przede wszystkim nałożenia dodatkowego obowiązku na organ w sytuacji wystapienia znacznego opóźnienia w rozpoznaniu sprawy. Jeśli bowiem sytuacja taka wystapi, organ zobowiązany jest poinformować o tym stronę. W takim powiadomieniu organ wskazuje przyczynę opóźnienia (§ 11 SCAP). Należy wszakże zauważyć, że pojęcie „znaczne opóźnienie” nie zostało zdefiniowane ustawowo.

Ważną nową cechą omawianego aktu jest to, że osoba, która inicjuje daną sprawę, może wnioskować do organu administracji publicznej o podjęcie decyzji w sprawie (rozstrzygnięcie sprawy), jeśli w ciągu sześciu miesięcy nie doszło do rozpoznania sprawy w pierwszej instancji (§ 12 zd. 1 SCAP). Taki wniosek musi zostać złożony na piśmie. Organ administracji publicznej w ciągu czterech tygodniu od daty złożenia wniosku powinien załatwić sprawę przez wydanie decyzji kończacej postępowanie lub odrzucić wniosek w drodze specjalnej decyzji (§ 12 zd. 2 SCAP). To ostatnie rozstrzygnięcie może następnie zostać zaskarżone przez stronę do sądu administracyjnego lub organu wyższego stopnia. Artykuł 49 SCAP stanowi, że jeżeli sąd (lub organ administracji publicznej) przychyli się do stanowiska skarżącego, wyznacza termin załatwienia sprawy przez organ prowadzący postępowanie administracyjne. Wprowadzono więc wprost możliwość zaskarżenia bezczynności lub przewlekłości postępowania organu administracyjnego. Zatem szwedzki ustawodawca zdecydował - w przeciwieństwie do poprzedniej ustawy - na wprowadzenie ogólnej regulacji, z której można wywieść obowiąek rozpoznania sprawy w terminie sześciu miesięcy od jej wszczęcia. Po upływie tego terminu strona postępowania uzyska uprawnienie w zakresie możliwości zwrócenia się z żądaniem załatwienia sprawy w terminie czterech tygodni. Organ ma wówczas prawo do żądania załatwienia sprawy, a organ powinien sprawę w tym terminie załatwić, względnie odrzucić wniosek, w którym zawarto żądanie załatwienia sprawy.

Szwedzki ustawodawca wprowadził do rodzimej procedury administracyjnej rozwiązanie zbliżone do ponaglenia obowiązującego w polskim k.p.a. Różnica wszakże polega - po pierwsze - na braku dewolutywności tego środka prawnego, a po drugie - na czasie, który organ administracji publicznej ma na załatwienie sprawy administracyjnej. W przypadku polskiej procedury administracyjnej maksymalny ustawowy czas na załatwienie sprawy (w praktyce oczywiście często wydłużany) to dwa miesiące. W przypadku omawianych regulacji wprowadzonych $\mathrm{w}$ Szwecji przesądzono, że środek prawny służący zwalczaniu bezczynności organów administracyjnych będzie przysługiwać dopiero po sześciu miesiącach od wszczęcia postępowania, ale termin ten będzie jednakowy dla wszystkich spraw administracyjnych, niezależnie od przebiegu samego procesu czy przedmiotu sprawy.

Stwierdzić trzeba więc, że biorąc pod uwagę regulacje prawa europejskiego, w szwedzkim systemie prawa administracyjnego dostrzeżono konieczność wprowadzenia środków zmierzających do zwalczania przewlekłości po-

${ }^{23}$ Zagorc (2015): 780. 
stępowania administracyjnego. Należy zauważyć, że nowa szwedzka ustawa procesowa nie zawiera regulacji dotyczących milczącego załatwienia sprawy czy też postępowań szczególnych (na wzór postępowania uproszczonego wprowadzonego ostatnio do polskiego k.p.a.).

\section{REGULACJE ZMIERZAJĄCE DO ZAPEWNIENIA SZYBKOŚCI POSTECPOWANIA ADMINISTRACYJNEGO OBOWIĄZUJĄCE W PRAWIE FIŃSKIM}

Również Finlandia - podobnie jak Szwecja i Polska - jest krajem, który posiada skodyfikowaną procedurę administracyjną. Obecnie obowiąujacca ustawa o postępowaniu administracyjnym (Hallintolaki) została uchwalona w 2003 r. ${ }^{24}$ Jest ona pokłosiem prac zmierzających do szeroko pojętego usprawnienia postępowania administracyjnego, a w omawianym zakresie interesujące jest to, że ma umożliwić realizację prawa do dobrej administracji, które jest wprost zapisane w Konstytucji Finlandii ${ }^{25}$. Co wyróżnia fińską ustawę regulująca procedurę administracyjna, to właśnie wielokrotne odesłania do pojęcia dobrej administracji i szeroko pojętej jakości działań organów administracji publicznej ${ }^{26}$. Jest to wynikiem regulacji rangi konstytucyjnej, albowiem fińska ustawa zasadnicza wprost odnosi się do pojęcia dobrej administracji. W $\S 21$ Konstytucji Finlandii przewidziano, że każdy ma prawo, by jego sprawa w należyty sposób i bez nieuzasadnionej zwłoki została rozpatrzona przez sąd lub inny urząd państwowy właściwy ustawowo, jak również by decyzje dotyczące jego praw i obowiązków poddane były kontroli sądu lub innego niezależnego organu $^{27}$. Ponadto ustawa procesowa winna zagwarantować jawność rozpatrywania sprawy, prawo do wysłuchania, prawo do otrzymania uzasadnienia decyzji, prawo do apelacji, jak również inne gwarancje rzetelnego procesu i dobrej administracji (§ 21 zd. 2 Konstytucji Finlandii) ${ }^{28}$. Ponadto, jak wskazuje się w piśmiennictwie, transparentność działań organów administracji publicznej jest wartością podstawową w zakresie standardów podejmowanych przez te organy czynności ${ }^{29}$.

Prawo do dobrej administracji, o czym mowa była wyżej, ma pierwszoplanowe znaczenie dla ukształtowania standardów procedury administracyjnej. Uchodzi ono za syntezę powszechnie aprobowanych zasad i wartości obowiązujących w postępowaniu przed organami w demokratycznym państwie prawnym, co uzasadnia jej postrzeganie w kategoriach terminu zbiorczego, oznaczającego rozmaite gwarancje ochrony prawnej w postępowaniu admini-

\footnotetext{
${ }^{24}$ Administrative Procedure Act (434/2003); dalej jako: FCAP.

25 Kmieciak, Królikowska-Olczak (2010): 139.

${ }_{26}$ Np. art. 1-3, art. 6-10, art. 53b-53c FCAP.

${ }_{27}$ Tekst w języku angielskim dostępny na: <https://www.finlex.fi/fi/laki/kaannokset/1999/

28 Maenpaa (2002): 414.

29 Wilhelmsson (2016): 15.
} en19990731.pdf>. 
stracyjnym ${ }^{30}$. Ponadto w Finlandii istotny nacisk kładzie się na elektronizację kontaktów pomiędzy obywatelami a władzą publiczna, nie tylko w przypadku prowadzenia postępowań administracyjnych, lecz także podejmowania wszelkich czynności w stosunku do podmiotów administrowanych ${ }^{31}$.

Już w art. 1 FCAP wskazano, że celem tej ustawy jest wdrożenie i promowanie dobrej administracji oraz ochrona jednostki w sprawach administracyjnych. Kolejnym celem ustawy jest promowanie jakości i wydajności usług administracyjnych. Ustawodawca fiński ewidentnie więc kładzie nacisk na efektywność systemu proceduralnego powiązaną z ochrona jednostki, przyjmując jednocześnie założenie konieczności zagwarantowania odpowiedniego poziomu świadczenia usług administracyjnych. Symptomatyczne jest też właśnie użycie pojęcia usługi administracyjnej, podczas gdy choćby w polskiej doktrynie zdecydowanie szerzej używane jest pojęcie władztwa administracyjnego. Co istotne, w fińskiej kodyfikacji procedury administracyjnej zostały zawarte również regulacje dotyczące umów administracyjnych, wraz ze wskazaniem, że przy zawieraniu tego rodzaju umów powinny być również przestrzegane podstawy dobrej administracji (art. 3 FCAP). Następnie w art. 7 FCAP wskazano, że to obowiązkiem organu jest dbałość o zorganizowanie korzystania z jego usług i rozpatrywania spraw w taki sposób, aby osoby, którym świadczy usługi w sprawach administracyjnych, były obsłużone odpowiednio, a organ władzy mógł skutecznie wykonywać swoje obowiązki. Pojęcia te nie sa zdefiniowane, w związku z tym należy ponownie odnieść się do prawa do dobrej administracji.

W procedurze fińskiej brak ustawowego określenia terminów załatwienia spraw. Artykuł 23 FCAP stanowi wyłącznie, że sprawę rozpatruje się bez zbędnej zwłoki. Nie ustalono, więc - jak w art. 35 k.p.a. - ogólnych terminów załatwienia spraw $\mathrm{w}$ postępowaniu administracyjnym ${ }^{32}$. Jednakże art. 23a FCAP stanowi, że w podstawowych kategoriach spraw wchodzących w zakres kompetencji poszczególnych organów administracji publicznej organ powinien określić spodziewany czas rozpatrywania spraw załatwianych w drodze decyzji administracyjnej na wniosek strony ${ }^{33}$. Ta regulacja nie ma zastosowania do rozpatrywania spraw z ustawowym terminem. Oznacza to, że - podobnie jak w prawie polskim - istnieje możliwość określenia konkretnego terminu załatwienia poszczególnych kategorii spraw administracyjnych. Dodatkowo w art. 49e FCAP wprowadzono zasadę, że odwołanie powinno być rozpatrzone niezwłocznie. Podobnie jak w przypadku regulacji polskich i szwedzkich, ustawodawca fiński zdecydował się na wprowadzenie ogólnej zasady szybkości postępowania, nie wprowadzając wszakże środka prawnego na podobieństwo ponaglenia $\mathrm{z}$ art. 37 k.p.a.

Strona nie jest jednak pozbawiona instrumentów prawnych zmierzających do zagwarantowania rozpoznania sprawy w możliwie najkrótszym terminie. Środkiem, który może być wykorzystany jako instrument zmierzający do prze-

\footnotetext{
${ }^{30}$ Krawczyk (2017): 32.

31 Kuopus (2010): 170.

32 Barlow (2017): 189.

${ }^{33}$ Zbliżone regulacje zawarte są w ustawodawstwach Hiszpanii i Estonii - zob. Zagorc (2015): 780.
} 
ciwdziałania przewlekłości działania administracji publicznej, jest skarga na działanie organów prowadzących postępowanie, przewidziana w art. 53a FCAP. Skargę taką rozpatruje organ nadzoru, który może zobowiązać organ prowadzący postępowanie do określonych działań, jak również wymierzyć „upomnienie”, chyba że charakter lub dotkliwość czynu stanowiącego przedmiot skargi wymaga dodatkowych środków w celu wszczęcia procedury dyscyplinarnej. W piśmiennictwie wskazuje się jednak, że brak środka prawnego, który przeciwdziałałby temu wprost, jest słabością procedury fińskiej, na co zwraca uwagę rzecznik praw obywatelskich Finlandii ${ }^{34}$.

Podobnie jak w przypadku regulacji obowiąujących w Szwecji, fińska ustawa procesowa nie zawiera unormowań dotyczacych możliwości milczacego załatwienia sprawy czy też postępowań uproszczonych.

\section{REGULACJE W PRAWIE POLSKIM}

Obecnie obowiąujacy k.p.a. ${ }^{35}$ od samego początku swojego obowiązywania zawiera ogólny nakaz kierowany do organu administracji publicznej formułujący obowiązek działania wnikliwie i szybko, posługując się możliwie najprostszymi środkami prowadzacymi do jej załatwienia (art. 10 k.p.a. $\mathrm{w}$ pierwotnym brzmieniu ${ }^{36}$ ). Oczywiste jest, że nakaz efektywnego prowadzenia postępowania wywodzić można już z norm zawartych w ustawie zasadniczej, choćby z zasady demokratycznego państwa prawnego i zasady praworządności ${ }^{37}$. Ta ostatnia, powtórzona zresztą w k.p.a., nakłada na organy administracji publicznej obowiązek działania na podstawie i w granicach prawa $^{38}$. Niewątpliwie podejmowanie czynności w zgodzie ze wspomnianymi nakazami rangi konstytucyjnej zakłada działanie sprawne i efektywne. Zasada szybkości postępowania, obecnie wynikająca z art. $12 \S 1$ k.p.a., stanowi normę optymalizacyjna, która ma zapewnić realizację pewnego stanu rzeczy w możliwie najwyższym stopniu, który to stopień uzależniony jest od możliwości prawnych i faktycznych ${ }^{39}$.

$\mathrm{Z}$ punktu widzenia omawianej tematyki istotne znaczenie maja ostatnie zmiany legislacyjne. Przypomnieć jedynie wypada, że na mocy ustawy z 7 kwietnia 2017 r. o zmianie ustawy - Kodeks postępowania administracyjnego i niektórych innych ustaw ${ }^{40}$ doszło do istotnych zmian w ukształtowaniu regulacji zmierzajacych do wymuszenia terminowego załatwienia spraw przez organy administracji publicznej. Ich celem było między innymi usprawnienie

34 Suvirata (2014): 184

35 T. jedn.: Dz. U. 2018, poz. 2096 ze zm.

${ }^{36}$ Dz. U. 1960, Nr 30, poz. 168.

37 Adamiak (2009): 17.

${ }^{38}$ Kowalski (2013): 277. Co do wątpliwości dotyczących możliwości ukształtowania prawa do rzetelnego procesu administracyjnego zgodnie z art. 45 Konstytucji RP - zob. Krawczyk (2017): 38.

39 Adamiak (2009): 417.

${ }^{40}$ Dz. U. 2017, poz. 935. 
procesu administracyjnego ${ }^{41}$. Podobne przyczyny konieczności wprowadzenia modyfikacji regulacji kodeksowej, co zauważa Wojciech Piątek, były wskazywane już przy okazji wcześniejszych nowelizacji k.p.a. ${ }^{42}$

Terminy załatwiania spraw określają czas efektywny, jakim dysponuje organ administracji publicznej załatwiający sprawę na jej rozpatrzenie i podjęcie decyzji. Terminy załatwienia sprawy zostały określone w art. 35 k.p.a. i maja charakter instrukcyjny. Dokonując oceny obowiązujących regulacji, należy zgodzić się z wyrażanym w piśmiennictwie poglądem, że niedookreślony sposób wskazania niezwłocznego terminu załatwienia sprawy i brak zakreślonych „kalendarzowo” terminów załatwienia spraw mogłyby powodować rozbieżności w ocenie działania organu z uwagi na możliwość odmiennej interpretacji niezwłocznego załatwienia spraw. Brak byłoby ram, w których spełniać ma się zasada szybkości postępowania ${ }^{43}$. Przy braku innych mechanizmów zabezpieczających samo ich ustanowienie wydaje się rozwiązaniem nieskutecznym ${ }^{44}$. Nałożenie obowiązku rozpatrzenia sprawy bez możliwości wdrożenia sankcji za jego naruszenie mogłoby w praktyce skutkować brakiem możliwości wyegzekwowania powinności działania w przewidziany prawem sposób. W przypadku polskiej procedury administracyjnej ustawodawca zdecydował się na wprowadzenie środka prawnego, jakim jest ponaglenie, a następnie umożliwienie stronie niezadowolonej z czasu załatwienia sprawy kontroli działań (zaniechań) organów administracji publicznej przez sądy administracyjne. Niewątpliwie instytucja ponaglenia odnosić się powinna do przypadków, które mogą być określone jako naganne, patologiczne, a tym samym ich pojawienie się $\mathrm{w}$ procesie administracyjnym jest niepożądane. Sytuacje określone jako bezczynność czy przewlekłość w rozumieniu art. 36 k.p.a. pozostają w jawnej kolizji z zasadą szybkości i sprawności postępowania ${ }^{45}$.

W piśmiennictwie wśród pozytywnych aspektów obecnie obowiązujących regulacji (np. określenie terminów załatwienia spraw i środków prawnych mających na celu wymuszenie ich przestrzegania) wskazuje się postępowanie uproszczone i kompleksową regulację dotycząca milczącego załatwienia sprawy $^{46}$, a wśród środków mających zapobiegać przewlekłości postępowania administracyjnego - wprowadzenie sprzeciwu od decyzji kasacyjnej. Instrumentem zmierzającym do przyspieszenia postępowań administracyjnych niewątpliwie jest także wprowadzenie do k.p.a. regulacji związanych z milczącym załatwieniem sprawy ${ }^{47}$. Ma ono obecnie coraz większe zastosowanie, milczenie

${ }^{41}$ Rządowy projekt ustawy o zmianie ustawy - Kodeks postępowania administracyjnego oraz niektórych innych ustaw z projektami aktów wykonawczych - druk sejmowy nr 1183; <http:// www.sejm.gov.pl/Sejm8.nsf/druk.xsp?nr=1183>. Ocena wprowadzonych zmian w doktrynie nie jest jednoznaczna - zob. Piątek (2017): 35-36; Zimmermann (2017): 7.

${ }^{42}$ Piątek (2017): 22. Należy jednak zauważyć, że już w okresie przedwojennym podejmowano próby wskazania możliwości przyśpieszenia postępowań administracyjnych - Langrod (1939): 5-6.

${ }_{43}$ Samulska (2017): 109.

${ }^{44}$ Adamiak (2009): 422.

${ }^{45}$ Mełgieś (2018): 12.

${ }^{46}$ Knysiak-Sudyka (2018b): 366.

${ }^{47}$ Uzasadnienie rządowego projektu ustawy o zmianie ustawy - Kodeks postępowania administracyjnego oraz niektórych innych ustaw, <http://www.sejm.gov.pl/Sejm8.nsf/druk.xsp?nr=1183>. 
organu administracji zaś nie może być obecnie każdorazowo traktowane jako działanie niezgodne z prawem, tam gdzie nie ma konieczności wyartykułowania woli władzy publicznej ${ }^{48}$.

Kolejnym elementem mającym zmierzać w kierunku przyspieszenia postępowania jest wprowadzenie do k.p.a. możliwości rozpatrzenia sprawy w trybie uproszczonym, co miało zbliżyć polską regulację do europejskiego standardu podejmowania działań przez organy administracji w rozsądnym terminie ${ }^{49}$. $\mathrm{W}$ piśmiennictwie wprowadzenie specjalnego trybu postępowania spotkało się $\mathrm{z}$ umiarkowanie pozytywnym przyjęciem ${ }^{50}$. Wskazuje się, że powinno to dotyczyć spraw prostych, mniejszej wagi, w których występuje nieskomplikowany stan faktyczny ${ }^{51}$. Należy jednak zwrócić uwagę na pewną niekonsekwencję ustawodawcy, który zarówno dla spraw załatwionych w trybie uproszczonym, jak i spraw wymagajacych postępowania wyjaśniającego ustanawia ten sam termin przeznaczony na ich załatwienie (termin miesięczny).

Podsumowując ten wątek rozważań, wypada zauważyć, że polski ustawodawca zdecydował się na wprowadzenie do k.p.a. mechanizmów, które nie obowiązują w ustawach procesowych Szwecji i Finlandii.

\section{PODSUMOWANIE}

Niewątpliwie szybkie załatwienie sprawy jest istotną wartością samego postępowania administracyjnego ${ }^{52}$. Rozpatrzenie sprawy w rozsadnym terminie stanowi w państwie prawa oczywiste oczekiwanie obywatela ${ }^{53}$. W doktrynie formułowano stanowisko, że sprawiedliwość nierychliwa jest zaprzeczeniem sprawiedliwości (justice delayed is justice denied) $)^{54}$. Wystapienie przewlekłości postępowania może skutkować tym, że załatwienie sprawy może dla strony stracić wszelką wartość (a z pewnościa jest zaprzeczeniem stabilności i pewności w stosunkach prawa), podważać autorytet władzy (wykonawczej lub sądowniczej) ${ }^{55}$. Nie ulega wątpliwości, że - jak to wskazano na początku niniejszych rozważań - wartość, którą są sprawność i szybkość postępowania, zazwyczaj będzie osiagana kosztem możliwości wnikliwego załatwienia sprawy czy też ograniczenia uprawnień stron postępowania. Nieprzypadkowo w piśmiennictwie wyrażano pogląd, że prawdziwym sprawdzianem dobrego państwa jest jego zdolność do posiadania dobrej administracji ${ }^{6}$. Nie oznacza

W uzasadnieniu ustawy nowelizującej k.p.a. wskazano, że poza przyśpieszeniem i uproszczeniem postępowania administracyjnego powinna ona usprawnić i zmniejszyć koszty funkcjonowania administracji publicznej.

${ }^{48}$ Gurba (2017): 85.

${ }^{49}$ Krawczyk (2017): 48.

${ }^{50}$ Jaśkowska (2018): 106; Szubiakowski (2017): 326-327.

${ }^{51}$ Knysiak-Sudyka, Klat-Wertelecka (2016): 101.

${ }_{52}$ Kotulska (2018): 414.

${ }^{53}$ Celińska-Grzegorczyk (2018): 53.

${ }^{54}$ Redelbach (1999): 279.

${ }^{55}$ Iserzon (1970): 62.

${ }^{56}$ Hamilton, Madison, Jay (2008): 502. 
to równocześnie, że szybkie działanie administracji jest - co już podniesiono w początkowej części rozważań - wartością nadrzędną.

Polski system prawny, podobnie jak system szwedzkiego postępowania administracyjnego, w odniesieniu do mechanizmów służących szybkiemu załatwieniu sprawy przeszedł ostatnio istotną zmianę, ale nie całościowa. Niewątpliwie jednak wprowadzone zmiany (w szczególności w zakresie instytucji ponaglenia, milczącego trybu załatwienia sprawy, mediacji czy postępowania uproszczonego) należy ocenić pozytywnie. Krytyczne oceny regulacji - dotyczących zwłaszcza milczącego załatwienia sprawy i mediacji - należy przyjąć jako postulaty modyfikacji i ulepszenia wprowadzonych unormowań. Wydaje się, że nie można stwierdzić, iż są one krytyką samych instytucji. Jak to już wskazywano w rodzimym piśmiennictwie, sam model milczącego załatwienia sprawy jest niewątpliwie instytucjonalnie pożądany, ale powinien być wprowadzany w sposób świadomy i roztropny, aby ostatecznie potrzeba przyspieszenia postępowania nie skutkowała zagrożeniem dla szeroko pojętego interesu publicznego lub interesu jednostki. Podsumowując analizę wprowadzonych zmian w zakresie regulacji zmierzających do zapewnienia sprawności postępowania administracyjnego - po upływie dwóch lat od ich wprowadzenia należy ocenić je pozytywnie. Również w piśmiennictwie wskazuje się, że obecna regulacja kodeksowa jest regulacją działajacca, sprawna i sprawdzona ${ }^{57}$. Nie zmienia to faktu, że w praktyce moga wystapić przypadki patologicznej bezczynności lub przewlekłości, które powinny być zwalczane za pomocą dostępnych środków prawnych, a konsekwencją tego może być pociagnięcie do odpowiedzialności osób winnych wystapienia takiego stanu rzeczy zgodnie z dyspozycja art. 38 k.p.a.

Zestawiajac normy zawarte w ustawach procesowych Polski, Szwecji i Finlandii, nie sposób nie dostrzec istotnych różnic, ale i podobieństw. W każdym z tych państw doszło do przesądzenia normatywnego powinności załatwienia sprawy bez zbędnej zwłoki. Równocześnie procedura fińska nie wyznacza ustawowych terminów załatwienia poszczególnych rodzajów spraw, jak również nie ustanawia szczególnego środka prawnego, który ma zapobiegać przewlekłości postępowania administracyjnego. W szwedzkim postępowaniu administracyjnym wprowadzono z kolei ostatnio termin (sześciomiesięczny), po upływie którego strona będzie uprawniona do złożenia skargi na przewlekłość postępowania. Porównywane z k.p.a. ustawy procesowe obowiązujące w krajach skandynawskich sprawiają wrażenie bardziej syntetycznych. Nie stanowi to zarzutu w stosunku do obecnie obowiązującej w Polsce regulacji, jednakże wyraźnie widoczne jest pozostawienie szeregu problemów interpretacyjnych praktyce działań organów administracji publicznej. Z drugiej strony należy zwrócić uwagę, że ustawodawca szwedzki pomimo funkcjonującego od lat kodeksowego modelu postępowania administracyjnego zdecydował się wprowadzić określony termin, który - jak można zakładać - jest maksymalnym terminem załatwienia sprawy. Zasadne wydaje się też postawienie pytania o możliwość dalszych modyfikacji samego procesu. Nie ulega też wątpliwości, że istotnym czynnikiem

${ }^{57}$ Bogusz (2018): 61; Tarno (2010): 847; Knysiak-Sudyka (2018a): 154. 
zmierzającym do przyśpieszenia postępowań administracyjnych może być ich prowadzenie (w tym w szczególności doręczanie pism procesowych) za pośrednictwem środków komunikacji elektronicznej ${ }^{58}$. Postulować należy więc wdrożenie rozwiązań sprzyjajacych elektronicznemu obiegowi korespondencji kierowanej zarówno przez organ prowadzący postępowanie do stron, jak i pism formułowanych przez strony, w szczególności w przypadku, w którym strona reprezentowana jest przez fachowego pełnomocnika. Skutkiem tego powinno być zmniejszenie kosztów postępowania administracyjnego, skrócenie czasu jego trwania, a konsekwencji - zwiększenie zaufania obywateli do organów władzy publicznej. Tego rodzaju rozwiązania powinny przynieść widoczny wzrost wydajności, dostępności i lepiej służyć obywatelom w ramach kontaktów z instytucjami sektora publicznego ${ }^{59}$. Nie ulega jednak wątpliwości, że zmiana ta będzie raczej wynikiem zmieniających się stosunków społecznych i informatyzacji społeczeństwa, albowiem trudne do zaakceptowania wydaje się wprowadzenie ustawowego nakazu elektronicznego obiegu dokumentów, niezależnie od woli stron postępowania. Ponadto wydaje się, że pożądanym kierunkiem zmian mogłoby być wdrożenie rozwiązań skutkujących zwiększeniem odpowiedzialności pracowników organów administracji publicznej za patologiczne przypadki bezczynności lub przewlekłości postępowania administracyjnego. Za zasadne należałoby uznać również rozszerzenie uprawnień strony do uzyskania rekompensaty za oczywiście zawinioną przewlekłość lub bezczynność.

Niewątpliwie stopień realizacji norm prawa procesowego, nakładającego na organy administracji publicznej określone obowiązki, w dużej mierze zależy od fachowości i zaangażowania urzędników wykonujących zadania publiczne. Wydaje się również oczywiste, że - jak to podkreśla się w piśmiennictwie - w miarę rosnącego obciążenia administracji publicznej obowiązkami i konieczności zaspokojenia potrzeb społeczeństwa w zakresie działań spoczywajacych na administracji publicznej, jak też formalizacji tych działań, model normatywny podejmowanych rozstrzygnięć staje się coraz bardziej złożony ${ }^{60}$. Wzrost kazuistyki kodeksowej, liczne nowelizacje przepisów oraz wzrost stopnia formalizmu procesowego sprzyjaja zjawiskom nadmiernej biurokracji, przewlekłości w podejmowaniu spraw oraz swoiście pojmowanemu legalizmowi urzędniczemu ${ }^{61}$. Ten aspekt pozostaje jednak poza zakresem rozważań natury prawnej, gdyż w przypadku działań prawodawcy, w odniesieniu do regulacji procesowych, możliwa jest ocena ukształtowania formy samego procesu czy też praw i obowiązków jego uczestników.

\section{Jan Olszanowski}

Uniwersytet im. Adama Mickiewicza w Poznaniu

jan.olszanowski@amu.edu.pl

https://orcid.org/0000-0003-3072-3413

${ }^{58} \mathrm{Na}$ niedostatki w zakresie mechanizmów doręczeń w postępowaniu administracyjnym zwraca również uwagę Lipowicz (2018): 188-189.

59 Szerzej Monarcha-Matlak (2018): 158.

${ }^{60}$ Kmieciak (2014): 256.

${ }^{61}$ Kmieciak (2017): A12. 
Adamiak, B. (2009). Od klasycznych do współczesnych gwarancji prawa do szybkiego załatwienia sprawy administracyjnej, [w:] J. Supernat (red.), Między tradycją a przyszłością w nauce prawa administracyjnego. Księga jubileuszowa dedykowana Profesorowi Janowi Bociowi. Wrocław: $17-27$.

Adamiak, B. (2015). Refleksje na temat dopuszczalności postępowania administracyjnego. Zeszyty Naukowe Sądownictwa Administracyjnego 11(5): 9-25.

Auby, B. (2014). Codification of Administrative Procedure. Brussels.

Barlow, A. (2017). Administrative law and human rights standards in legal aid: an overview with examples from Finland and England \& Wales. European Public Law 23(1): 165-191.

Bignami, F. (2004). Foreword. Law and Contemporary Problems 68(1): 1-17.

Bogdan, M. (2013). Concise Introduction to Comparative Law. Amsterdam.

Bogusz, M. (2018). Kodyfikacja postępowania administracyjnego o pojęcie postępowania administracyjnego, [w:] Z. Kmieciak, W. Chróścielewski (red.), Idea kodyfikacji w nauce prawa administracyjnego procesowego. Księga pamiątkowa Profesora Janusza Borkowskiego. Warszawa: 55-64.

Celińska-Grzegorczyk, K. (2018). Odpowiedzialność odszkodowawcza za naruszenie prawa strony do rozpatrzenia sprawy bez nieuzasadnionej zwłoki w postępowaniu sądowoadministracyjnym po nowelizacji z 30 listopada 2016 r. Zeszyty Naukowe Sądownictwa Administracyjnego 2: 53-63.

Gurba, W. (2017). Bezczynność i przewlekłość postępowania. Milczące załatwianie spraw, [w:] Z. Kmieciak (red.), Raport Zespołu eksperckiego z prac w latach 2012-16. Reforma prawa o postępowaniu administracyjnym. Warszawa: 83-98.

Hamilton, A., Madison, J., Jay, J. (2008). The Federalist Papers. Oxford.

Hauser, R., Niewiadomski, Z., Wróbel, A. (2017). System prawa administracyjnego. Tom 9: Prawo procesowe administracyjne. Warszawa.

Iserzon, E., Starościak, J. (1970). Kodeks postępowania administracyjnego. Komentarz. Teksty, wzory i formularze. Warszawa.

Jaśkowska, J. (2018). Kodyfikacja administracyjnych postępowań uproszczonych - postulaty de lege ferenda, [w:] Z. Kmieciak, W. Chróścielewski (red.), Idea kodyfikacji w nauce prawa administracyjnego procesowego. Księga pamiątkowa Profesora Janusza Borkowskiego. Warszawa: 95-108.

Kmieciak, Z. (1994). Idea sprawiedliwości proceduralnej w prawie administracyjnym (założenia teoretyczne i doświadczenia praktyki). Państwo i Prawo 49(10): 55-64.

Kmieciak, Z. (2010). Postępowania administracyjne w Europie. Warszawa.

Kmieciak, Z. (2014). Zarys teorii postępowania administracyjnego. Warszawa.

Kmieciak, Z. (2017). Słowo wstępne, [w:] Z. Kmieciak (red.), Raport Zespołu eksperckiego z prac w latach 2012-16. Reforma prawa o postępowaniu administracyjnym. Warszawa: 11-15.

Knysiak-Sudyka, H. (2018a). Kodeks postępowania administracyjnego - dokąd zmierza ustawodawca, [w:] Z. Kmieciak, W. Chróścielewski (red.), Idea kodyfikacji w nauce prawa administracyjnego procesowego. Księga pamiątkowa Profesora Janusza Borkowskiego. Warszawa: 153-164.

Knysiak-Sudyka, H. (2018b). Nowelizacja Kodeksu postępowania administracyjnego - aspekt pozytywny, [w:] J. Jagielski, M. Wierzbowski (red.), Prawo administracyjne dziś i jutro. Materiały na XXV Zjazd Katedr Prawa i Postępowania Administracyjnego, Warszawa, 2527.06.2018 r. Warszawa: 361-368.

Knysiak-Sudyka, H., Klat-Wertelecka, L. (2016). Model administracyjnego postępowania uproszczonego. Państwo i Prawo 71(7): 93-108.

Kopeć, J. (2018). „Ponaglenie” - nowa instytucja w Kodeksie postępowania administracyjnego służąca przeciwdziałaniu bezczynności organów administracji publicznej i przewlekłości postępowania administracyjnego. Zeszyty Naukowe Zbliżenia Cywilizacyjne 14(1): 34-49.

Kotulska, M. (2018). Zasada szybkości i prostoty postępowania, [w:] G. Łaszczyca, A. Matan (red.), System prawa administracyjnego procesowego. Tom 2. Część 2: Zasady ogólne postępowania administracyjnego. Warszawa: 414-434.

Kowalski, M. (2013). Terminy w postępowaniu administracyjnym i sądowoadministracyjnym. Wrocław.

Kovač, P., Kotnik, Ž. (2018). Performance of authorities in administrative procedures: lessons from statistical data. Croatian and Comparative Public Administration 18(4): 531-553. 
Kuopus, J. (2010). Towards electronic administration, [w:] Parliamentary Ombudsman. 90 years, Sastamala: $170-183$.

Langrod, J.S. (1939). O tzw. milczeniu władzy. Studium prawno-administracyjne. Kraków-Warszawa.

Lipowicz, I. (2018). Wpływ nowych technologii na procesy decyzyjne w administracji publicznej [w:] Z. Kmieciak, W. Chróścielewski, Idea kodyfikacji w nauce prawa administracyjnego procesowego. Księga pamiątkowa Profesora Janusza Borkowskiego. Warszawa: 181-196.

Lofven, S. (2017). Raport rządowy 2016/17: 180 Nowoczesne i zarządzanie pewnością prawnąnowe prawo administracyjne (Regeringensproposition 2016/17:180 En modern ochrättssäkerförvaltning-nyförvaltningslag). Sztokholm.

Maenpaa, O. (2002). Administrative procedure, [w:] J. Púyhúnen, An Introduction to Finnish Law. Helsinki: 414-435.

Mełgieś, K. (2018-2019). Przeciwdziałanie przewlekłości postępowania administracyjnego i bezczynności organu. Edukacja Prawnicza 3: 10-17.

Monarcha-Matlak, A. (2018). Wpływ komunikacji elektronicznej na prawo administracyjne, [w:] J. Jagielski, M. Wierzbowski (red.), Prawo administracyjne dziś i jutro. Warszawa: 152-159.

Nergelius, J. (2011). Constitutional Law in Sweden. Alphen aan den Rhijn.

Niewiadomski, Z. (2002). Prawo administracyjne. Część procesowa. Warszawa.

Ortwein II, B.M. (2003). The Swedish legal system: an introduction. Indiana International and Comparative Law Review 13(2): 405-445.

Ostojski, P. (2017). Instrumentalizacja prawa o postępowaniu administracyjnym. Poznań.

Pecaric, M. (2011). Administrative culture. Croatian and Comparative Public Administration 11(2): 379-409.

Piątek, W. (2017). Kodeks postępowania administracyjnego w świetle ustawy nowelizującej z dnia 7 kwietnia 2017 r. - ogólna charakterystyka zmian. Zeszyty Naukowe Sądownictwa Administracyjnego 13(5): 21-36.

Redelbach, A. (1999). Sądy a ochrona praw człowieka. Toruń.

Samulska, M. (2017). Zasada szybkości postępowania administracyjnego w prawie polskim. Warszawa.

Szubiakowski, M. (2018). Postępowanie uproszczone - nowa instytucja polskiej procedury administracyjnej, [w:] Z. Kmieciak, W. Chróścielewski (red.), Idea kodyfikacji w nauce prawa administracyjnego procesowego. Księga pamiątkowa Profesora Janusza Borkowskiego. Warszawa: $325-332$.

Świątkiewicz, J. (2007). Europejski kodeks dobrej administracji. Warszawa.

Tarno, J.P. (2010). Psucie Kodeksu postępowania administracyjnego, [w:] J. Niczyporuk (red.), Kodyfikacja postępowania administracyjnego. Na 50-lecie K.P.A. Lublin: 847-856.

Weitz, K. (2009). Między system dyskrecjonalnej władzy sędziego a systemem prekluzji, [w:] H. Dolecki, K. Flaga-Gieruszyńska (red.), Ewolucja polskiego postępowania cywilnego wobec przemian politycznych, społecznych i gospodarczych. Materiały konferencyjne Ogólnopolskiego Zjazdu Katedr Postępowania Cywilnego. Szczecin-Niechorze 28-30.9.2007. Warszawa: 73-98.

Wenander, H. (2018). Sweden: Deference to the Administration in Judicial Review. Paper presented at The XXth Congress of International Academy of Comparative Law (AIDC/IACL). Fukuka.

Wojciechowska, K. (2018). Sprzeciw od decyzji kasacyjnej jako narzędzie walki z przewlekłościa postępowania administracyjnego, [w:] J. Jagielski, M. Wierzbowski (red.), Prawo administracyjne dziś i jutro. Materiały na XXV Zjazd Katedr Prawa i Postępowania Administracyjnego, Warszawa, 25-27.06.2018 r. Warszawa: 407-499.

Wilhelmsson, N. (2016). Implementation of e-democracy in Finland - new opportunities for effective, transparent and collaborative governance, [w:] E-democracy, E-Governance and Public Sector Reform Revisited - Experiences of The Main Themes of the PADOS project in Finland and Estonia. Kurikka: 11-30.

Zagorc, Š. (2015). Decision-making within a reasonable time in administrative procedures. Hrvatska komparativna javna uprava (Croatian and Comparative Public Administration) 15(4): 769-790.

Zimmermann, J. (2017). Kilka refleksji o nowelizacji k.p.a. Państwo i Prawo 72(8): 3-24. 


\section{THE PRINCIPLE OF EFFICIENCY OF ADMINISTRATIVE PROCEDURE IN SELECTED SCANDINAVIAN COUNTRIES AND POLAND}

\section{Sum mary}

The subject of this study is an analysis of legal norms focused on the efficiency of administrative procedure, including norms establishing the time limits for the administrative authorities to deal with cases and legal remedies to ensure that cases are settled without unnecessary delay. The considerations seek to verify whether the currently applicable regulations in the Polish legal system protect the right for cases to be considered in a fair manner, without undue delay, and whether they do not differ from the solutions adopted in other countries of the European Union. To compare models of administrative procedure in these terms, two Scandinavian procedures were chosen: Swedish and Finnish. It is widely accepted that Scandinavian countries are mature democracies, highly regarded for the administrative services provided to citizens and their guarantees of human rights protection. The Swedish model of administrative procedure was chosen due to the introduction of a new Administrative Procedure Act. In turn, the Finnish legal system is considered one of the most citizen-friendly public administration systems. In both Sweden and Finland, a number of improvements have been made to popularize e-administration, including actions taken to facilitate administrative procedure.

Keywords: administrative procedure; delay in administrative procedure; time limits for the settlement of cases 
